\title{
Education for Advancing the Implementation of the Bioeconomy Goals: An Analysis of Master Study Programmes in Bioeconomy
}

\author{
Jelena PUBULE ${ }^{1 *}$, Andra BLUMBERGA², Stelios ROZAKIS ${ }^{3}$, Anita VECINA $^{4}$, \\ Antra KALNBALKITE ${ }^{5}$, Dagnija BLUMBERGA ${ }^{6}$

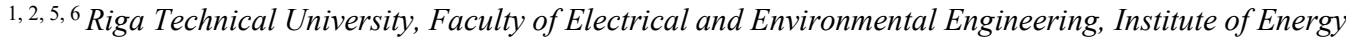 \\ Systems and Environment, Azenes iela 12/K1, LV-1048, Riga, Latvia \\ ${ }^{3}$ School of Environmental Engineering, Technical University of Crete, 73100 Chania, Greece \\ ${ }^{4}$ Riga Technical University, Kalku iela 1, LV-1658, Riga, Latvia
}

\begin{abstract}
Bioeconomy in Europe has become one of the leading courses for sustainable and resource-efficient development. Main aspects of bioeconomy: development of new technologies and processes, development of markets and competitiveness for bioeconomy can be implemented through higher education and transformative knowledge for building a sustainable bioeconomy. Over the past year, new bioeconomy-related Master study programmes have been created and have integrated bioeconomy goals into their research, programme aims and learning outcomes. During the research the set of competences based on sustainable development competences and bioeconomy competences have been created. The integration of competences for bioeconomy development in higher education can be seen as an important step in transformation towards knowledge-based bioeconomy. On this basis, 10 Master study programmes across Europe were analysed in order to find out the actual integration of competences in different study programmes for bioeconomy. Results of the analysis show that transdisciplinary competence, learning competence, interdisciplinary competence and system-thinking competence are strongly integrated into the study programmes. The analysis also shows that the integration of other competences, like anticipatory competence, normative competence, strategic competence and interpersonal competence can be improved in the future.
\end{abstract}

Keywords - Sustainable higher education; competences; green innovation; bioeconomy integration assessment

\section{INTRODUCTION}

Bioeconomy in Europe has become one of the leading courses for sustainable and resourceefficient development. Main aspects of bioeconomy: development of new technologies and processes and development of markets and competitiveness for bioeconomy [1] can be implemented through higher education and transformative knowledge for building a sustainable bioeconomy. Intellectual capital gained through the knowledge-based bioeconomy became crucial for the development agenda of the European Union [2]. Therefore, the implementation of bioeconomy in Europe will be in a short loop with education and research [3]-[6]. The successful

\footnotetext{
* Corresponding author.

E-mail address: jelena.pubule@rtu.lv

(C)2020 Jelena Pubule, Andra Blumberga, Stelios Rozakis, Anita Vecina, Antra Kalnbalkite, Dagnija Blumberga. This is an open access article licensed under the Creative Commons Attribution License (http://creativecommons.org/ licenses/by/4.0), in the manner agreed with Sciendo.
} 
development of bioeconomy requires new skills from graduates of higher education based on revised model of intellectual improvement and knowledge-based technology innovation [7], [8].

The Green deal [9] set ambitious targets for European Member states to strive for with the goal to reach the climate neutrality by 2050 , with a special attention to a number of sectors crucial to fulfil its ambitious aims: clean energy, sustainable industry, building and renovating, sustainable mobility, biodiversity, farm to fork and eliminating pollution. As bioeconomy instead of fossil fuels rely on renewable biomass for the production of value-added products and these products will be produced in accordance with a cascade principle, the development of bioeconomy can help to reach The Green deal goals and targets.

Golembiewski et al. [10] identified three main bioeconomy challenges: knowledge base, converging technologies and commercialization issues. The role of higher education in crucial for all three of these challenges, cause innovation and intellectual capital development can be achieved only with adequate skills and knowledges. In accordance with Val Lancker et al. [11] five factors impacting implementation of innovation development in bioeconomy:

1. Radical innovation.

2. Complex knowledge base.

3. Intense cooperation.

4. Commercialization and adoption.

5. Complex and fragmented policy schemes [11].

The implementation of bioeconomy goals should be absorbed from the systematic perspective, considering different stakeholder's groups. Working on overcoming of bioeconomy challenges special attention should be paid to environmentally sustainable economy development, because ecologically correct business practices [12], [13] can reduce the impact on environment and speed up the achievement of Green Deal goals. Montalvo et al. [14], [15] pointed out that the creation of greener technologies includes technological capabilities through well prepared high-quality human resources, equipment and laboratories. Different authors have carried out studies, according to which development of environmentally sustainable innovation and green innovation requires innovation-oriented learning and acquisition of specific skills [16]-[19]. Considering the above mentioned, the best practices for teaching bioeconomy, environmental responsibility and green innovations in Europe should be discussed and analysed.

\section{Methodology}

A research was conducted to propose an effective framework to evaluate the effectiveness of Master study on Bioeconomy with a focus on competence-based education and development of sustainable innovations.

During the first and second step of the research the research definition, objectives and research questions were defined. Conduction of the research started with data collection and analysis. During this step the systematic review of scientific literature on teaching bioeconomy in higher education, competences for sustainable development and bioeconomy, innovation indicators was conducted.

During the next step of the research most significant innovation indicators for bioeconomy were identified and selected.

The integration of competences for bioeconomy development in higher education can be seen as an important step in transformation towards knowledge-based bioeconomy. During the next step key competences for bioeconomy have been defined. During the research the set of competences based on sustainable development competences and bioeconomy competences have been created. 
Over the past year, new bioeconomy-related Master study programmes have been created and have integrated bioeconomy goals into their research, programme aims and learning outcomes.

A systematic review [20]-[22] of existed Master study programmes on Bioeconomy was required. For identification and selection of the most significant indicators in teaching of bioeconomy in higher education, study programmes in Europe, including joint programmes and Erasmus Mundus joint programmes were investigated.

Based on this examination, ten Master study programmes across Europe were analysed in order to find out the actual integration of competences in different study programmes for bioeconomy.

The methodological algorithm of the research is shown in Fig. 1.

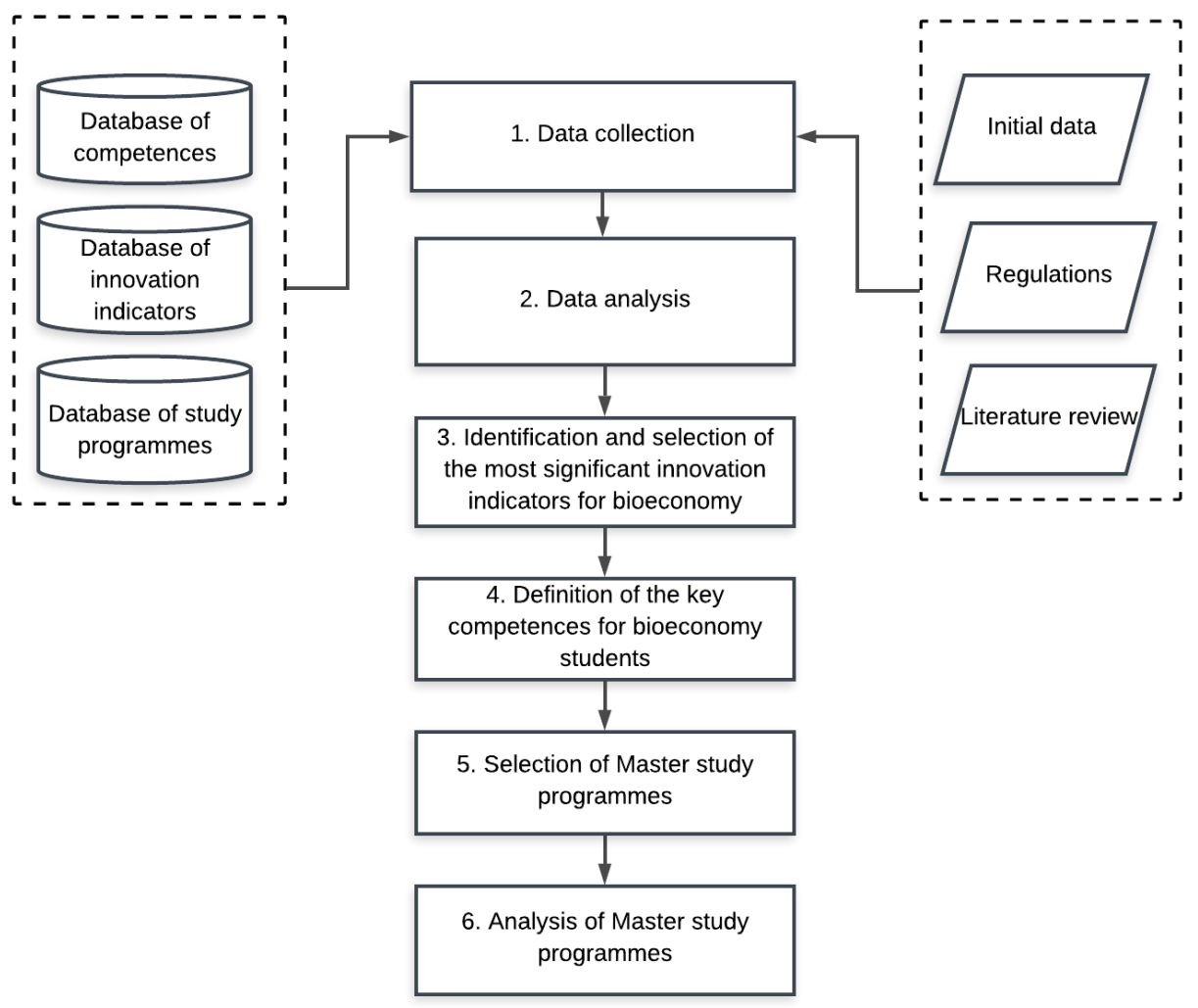

Fig. 1. Methodological algorithm.

\section{RESUltS AND DisCUSSION}

\subsection{The Role of Higher Education in Innovation Development in the Bioeconomy}

The development of the bioeconomy is related with the promotion of innovation. The interaction of innovation with the bioeconomy context should be defined. Through innovation and use of 
knowledge-based technologies bioeconomy provide entirely new products, at the same time adapting the existing technologies and products to reach the demands of sustainable economy [23].

How to measure innovation in the bioeconomy? Wydra [24] had analysed innovation indicators in bioeconomy, including research and development activities, bibliometrics and patents, human resources and commercialization and the impact of innovation. Ribeiro and Cherobim [25] described stages of the innovation process and Van Lancker et al. [11] analysed the role of universities in innovation in the bioeconomy. Fig. 2 shows the innovation process in bioeconomy, including innovation process, stages, involvement of university and innovation indicators. Universities play the core role in the innovation process.

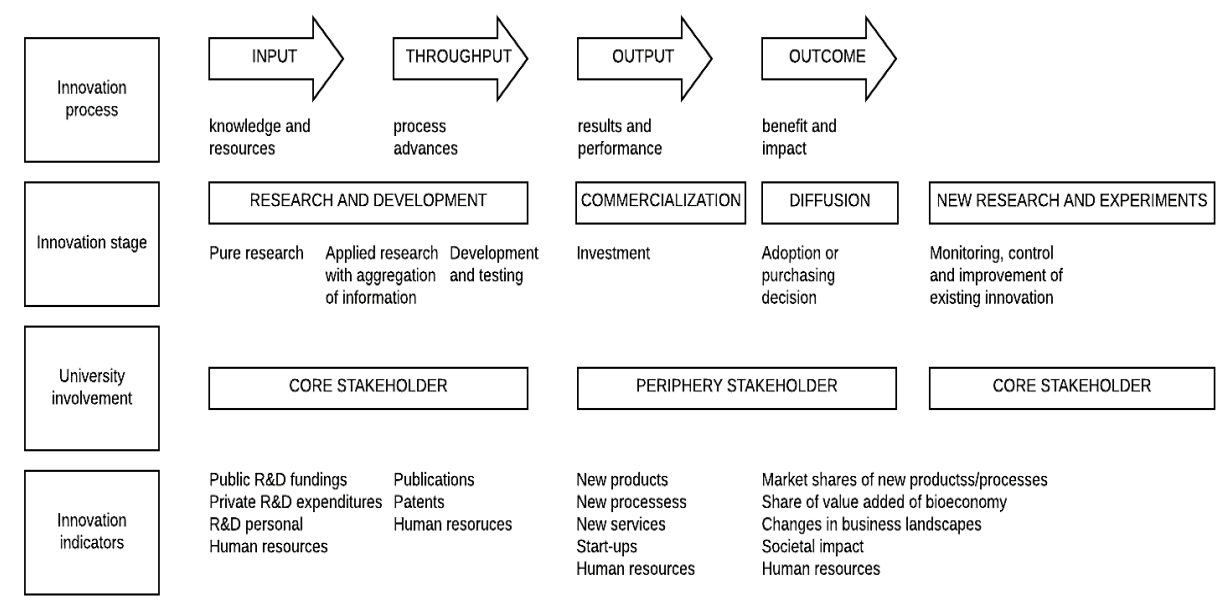

Fig. 2. Innovation process and indicators in bioeconomy.

\subsection{The Integration of Competences for Bioeconomy Development in Higher Education}

European Commission has defined the theoretical concept of Knowledge-Based-Bioeconomy (KBBE) as life science knowledge transformation process into eco-efficient, new and sustainable products [26]. The transformation process of the existing production system towards KBBE will increase demand for the high-skilled and highly qualified workers. To analyse the qualification needed, the competences and knowledge for building a sustainable bioeconomy were analysed. Due to the global changes and transition to bioeconomy and circular economy, new ways of knowledge production and decision-making at university level should be developed [27].

In accordance with Segalas et al. [28], education, although an important condition, does not guarantee a change to sustainability. Engineering students upon graduating should have systems thinking and transdisciplinary competence. The same statement can be addressed to bioeconomy. Transdisciplinary in contest of engineering education is considered a competence for sustainability [29]. Lambrechts et al. [30] analysed the integration of competences for sustainable development in higher education via a holistic, interdisciplinary and transdisciplinary approach and competence-based education. Authors analysed how competences for sustainable development, such as responsibility, emotional intelligence, system orientation, future orientation, personal involvement and action skills were integrated into bachelor study programmes in management. Weak et al. [31] defined system-thinking competence, anticipatory competence, 
normative competence, strategic competence and interpersonal competence as main competences for sustainability.

The transition towards a bioeconomy requires well prepared bioeconomy professionals with basic and key competences acquitted through interdisciplinary educational process and new learning environments. Sustainability is considered to be a basic principle of bioeconomy; therefore, the competences for sustainability can be used as the basis for the competences for bioeconomy [32].

The programmes on bioeconomy are trying to integrate innovative learning and facilitate the development of interdisciplinary competence acquiring the ability to integrate and collaborate [33]. Learning competence include self-directed learning, collaborative learning and problem-oriented learning [34].

The integration of competences for sustainable development and bioeconomy competences can be seen as an important step in higher education for advancing the implementation of the bioeconomy goals.

There is a lack of information on the actual status of the integration of competences in existing Master study programmes on bioeconomy. The competences used for the analysis of Master study programmes on bioeconomy are shown in Table 1 .

\section{TABLE 1. COMPETENCES FOR BIOECONOMY USED FOR THE ANALYSIS}

\begin{tabular}{ll}
\hline Competence & Discourse of Competence \\
\hline $\begin{array}{l}\text { System-thinking } \\
\text { competence }\end{array}$ & $\begin{array}{l}\text { The ability to collectively analyse complex systems across different domains of } \\
\text { sustainability and bioeconomy [31]. }\end{array}$ \\
$\begin{array}{l}\text { Anticipatory } \\
\text { competence }\end{array}$ & $\begin{array}{l}\text { The ability to collectively analyse and evaluation in bioeconomy and sustainability } \\
\text { issues [31]. }\end{array}$ \\
$\begin{array}{l}\text { Normative } \\
\text { competence }\end{array}$ & $\begin{array}{l}\text { The ability to collectively map, specify, apply, reconcile, and negotiate sustainability values, } \\
\text { principles, goals, and targets [31]. }\end{array}$ \\
$\begin{array}{l}\text { Strategic } \\
\text { competence }\end{array}$ & $\begin{array}{l}\text { The ability to collectively design and implement interventions, transitions, and } \\
\text { transformative governance strategies towards bioeconomy sustainability [31]. }\end{array}$ \\
$\begin{array}{l}\text { Interpersonal } \\
\text { competence }\end{array}$ & $\begin{array}{l}\text { Advanced skills in communicating, deliberating and negotiating, collaborating, leadership, } \\
\text { pluralistic and trans-cultural thinking, and empathy [31]. }\end{array}$ \\
$\begin{array}{l}\text { Transdisciplinary } \\
\text { competence }\end{array}$ & $\begin{array}{l}\text { Advances skills in transcendence, problem solving, innovation, interdisciplinary research, } \\
\text { transgression [28]. }\end{array}$ \\
$\begin{array}{l}\text { Learning } \\
\text { competence }\end{array}$ & $\begin{array}{l}\text { The ability to self-directed learning, collaborative learning and problem-oriented } \\
\text { learning [33]. }\end{array}$ \\
$\begin{array}{l}\text { Interdisciplinary } \\
\text { competence }\end{array}$ & $\begin{array}{l}\text { The ability to integrate disciplinary perspectives and their insights to advance understanding } \\
\text { of complex problems with the goal of applying the understanding to a real-world problem } \\
\text { [30]. }\end{array}$ \\
\hline
\end{tabular}

\subsection{Analysis of Master study programmes on bioeconomy}

In the last years several universities in Europe have established programmes on topics related with bioeconomy. For the analysis from European master programmes on bioeconomy were selected. The study programme selection was done through the master study programmes search pages and through the search on specific home pages about bioeconomy.

Only full time Master Study programmes were selected. Search results have shown that study programmes on bioeconomy spread around Europe from North Europe (Finland and 
Estonia), Western Europe (Germany, Austria, Netherlands, France Belgium), Eastern Europe (Rumania), Southern Europe (Italy, Spain) and the United Kingdom.

For the moment the most of the study programmes are in Western Europe. Netherlands are the leaders with four Master study programmes on bioeconomy. Germany, France, and the United Kingdom have more than one study programme on bioeconomy. Seven Master study programmes are University study programmes, two are joint Master study programmes and one is Erasmus Mundus Joint Master study programme. The overall focus of study programmes is on bioeconomy with specialization in different aspects of bioeconomy, such as forestry, biotechnology, circular economy, chemical engineering, biobased materials, bio innovations, etc.

The sampling resulted in the following 10 study programmes presented in Table 2.

TABle 2. MAster Study Programmes on Bioeconomy

\begin{tabular}{|c|c|c|c|}
\hline University & $\begin{array}{l}\text { The name of } \\
\text { the programme }\end{array}$ & $\begin{array}{l}\text { Study } \\
\text { time }\end{array}$ & Description \\
\hline Maastricht University (Netherlands) & $\begin{array}{l}\text { Biobased } \\
\text { Materials }\end{array}$ & $\begin{array}{l}2 \text { years } \\
\text { full time }\end{array}$ & $\begin{array}{l}\text { Focus on discovery of new materials and } \\
\text { sustainable production methods of } \\
\text { bioresources [35]. }\end{array}$ \\
\hline Utrecht University (Netherlands) & $\begin{array}{l}\text { Bio Inspired } \\
\text { innovation }\end{array}$ & $\begin{array}{l}2 \text { years } \\
\text { full time }\end{array}$ & $\begin{array}{l}\text { Focus on development of circular } \\
\text { business-models and bio inspired research } \\
\& \text { innovations [36]. }\end{array}$ \\
\hline $\begin{array}{l}\text { Wageningen University and } \\
\text { Research (Netherlands) }\end{array}$ & $\begin{array}{l}\text { Biobased } \\
\text { Sciences and } \\
\text { Biosystems } \\
\text { Engineering } \\
\text { (and } \\
\text { Biotechnology) }\end{array}$ & $\begin{array}{l}2 \text { years } \\
\text { full time }\end{array}$ & $\begin{array}{l}\text { Focus on biobased economy from an } \\
\text { interdisciplinary perspective [37]. }\end{array}$ \\
\hline University of Edinburgh (UK) & $\begin{array}{l}\text { Management of } \\
\text { Bioeconomy, } \\
\text { Innovation and } \\
\text { Governance }\end{array}$ & $\begin{array}{l}2 \text { years } \\
\text { full time }\end{array}$ & $\begin{array}{l}\text { Focus on such aspects of bioeconomy as } \\
\text { sustainable innovation and bringing new } \\
\text { technologies to existing and emerging } \\
\text { markets [38]. }\end{array}$ \\
\hline University of Strathclyde (UK) & $\begin{array}{l}\text { Industrial } \\
\text { Biotechnology }\end{array}$ & $\begin{array}{l}1 \text { year } \\
\text { full time }\end{array}$ & $\begin{array}{l}\text { Focus on understanding of the current } \\
\text { developments in industrial biotechnology } \\
\text { [39]. }\end{array}$ \\
\hline $\begin{array}{l}\text { The University of Hohenheim } \\
\text { (Germany) }\end{array}$ & Bioeconomy & $\begin{array}{l}2 \text { years } \\
\text { full time }\end{array}$ & $\begin{array}{l}\text { Focus on biobased economy through } \\
\text { inter- and transdisciplinary approach [40]. }\end{array}$ \\
\hline University of Helsinki (Finland) & Forest Sciences & $\begin{array}{l}2 \text { years } \\
\text { full time }\end{array}$ & $\begin{array}{l}\text { Focus on forest bioeconomy business and } \\
\text { policy [41]. }\end{array}$ \\
\hline $\begin{array}{l}\text { Joint Study Programme: University } \\
\text { of Eastern Finland, } \\
\text { AgroParisTech (France), University } \\
\text { of Freiburg (Germany), University } \\
\text { of Lleida (Spain), University of } \\
\text { Natural Resources and Life } \\
\text { Sciences (Austria), Transilvania } \\
\text { University of Brașov (Romania) }\end{array}$ & $\begin{array}{l}\text { European } \\
\text { Forestry }\end{array}$ & $\begin{array}{l}2 \text { years } \\
\text { full time }\end{array}$ & $\begin{array}{l}\text { Focus on sustainable resource } \\
\text { management with an emphasis on current } \\
\text { bioeconomy issues [42]. }\end{array}$ \\
\hline $\begin{array}{l}\text { Joint Master: University of } \\
\text { Bologna, University of Milano- } \\
\text { Bicocca, University of Naples } \\
\text { Federico II, } \\
\text { University of Turin (Italy) }\end{array}$ & $\begin{array}{l}\text { European Master } \\
\text { in Bioeconomy } \\
\text { in the Circular } \\
\text { economy }\end{array}$ & $\begin{array}{l}1 \text { year } \\
\text { full time }\end{array}$ & $\begin{array}{l}\text { Focus on bio-based goods and services } \\
\text { industry using biological resources and } \\
\text { bio-technological processes [43]. }\end{array}$ \\
\hline
\end{tabular}


Erasmus Mundus Joint Master:

Paris Institute of Technology for

Life, Food and Environmental

Sciences (France),

University of Reims-Champagne-

Ardenne (France),

Aalto University (Finland), Tallinn

University of Technology (Estonia),

University of Liège (Belgium)

$\begin{array}{ll}\text { European Master } & 2 \text { years } \\ \text { in Biological } & \text { full time } \\ \text { and Chemical } & \\ \text { Engineering for } & \\ \text { a Sustainable } & \\ \text { Bioeconomy } & \end{array}$

$\begin{array}{ll}\text { European Master } & 2 \text { years } \\ \text { in Biological } & \text { full time }\end{array}$

Focus on biotechnology, bioprocess

design and upscaling, and biobased products engineering, with complementary focus on soft skills including project management [44].

A framework of analysis was developed using competences for bioeconomy defined by Wiek et al. [31], Repko et al. [33], Barth and Burandt [34] and Tejedor et al. [29], and competences acquitted in the study courses of each study programme. The research used competences for bioeconomy as the basis for the analysis of study programmes. Each competence was interpreted in the competence scheme. For the analysis syllabus, study programmes descriptions and study course descriptions for each study programme have been used. The goal was to express the integration of the competences for bioeconomy in each study programme: (1) little or no integration, (2) minimal integration, (3) moderate integration, (4) good integration. Table 3 provides an overview of results of analysis of University of Edinburgh study programme "Management of Bioeconomy, Innovation and Governance".

TABle 3. EXAmPle of ANALysis of Study PROGRAMME INDIVIDUAl COMPETENCE MATRICES

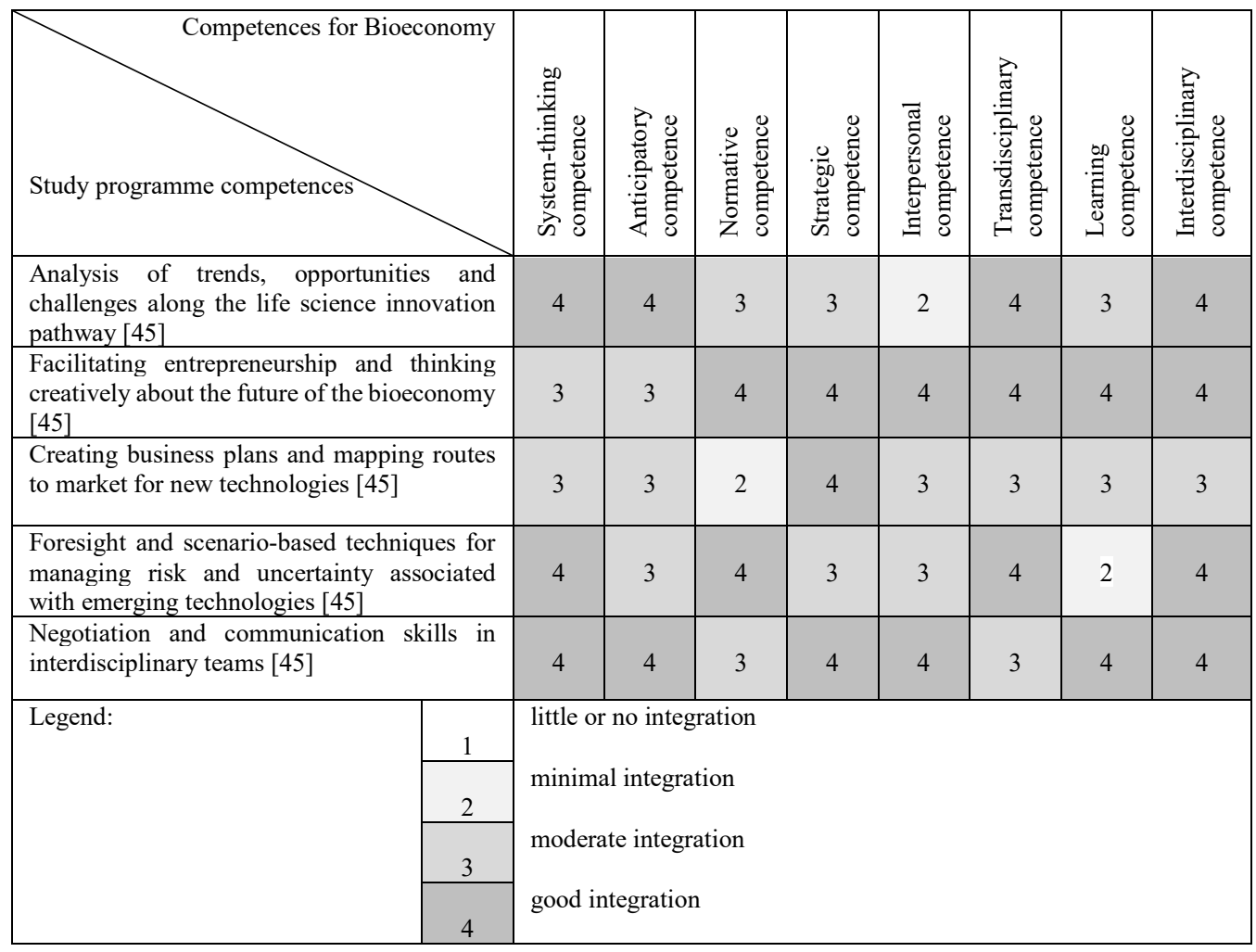


Considering the fact that analysed study programmes are designed especially for the bioeconomy studies, overall bioeconomy and sustainable development competences are well integrated into the study programmes. In existing study programmes on Bioeconomy in Europe transdisciplinary competence, learning competence, interdisciplinary competence and systemthinking competence are strongly integrated into study programmes. The integration of other competences, like anticipatory competence, normative competence, strategic competence and interpersonal competence can be stronger. This illustrated that translation towards these competences for sustainable development and bioeconomy in a future must be intensified.

The result of the analysis on the integration of bioeconomy competences in study programme competences are shown in Table 4.

\section{TABle 4. THE INTEGRATION OF BIOECONOMy COMPETENCES IN THE StUdy PROGRAMme COMPETENCES}

\begin{tabular}{|c|c|c|c|c|c|c|c|c|}
\hline $\begin{array}{l}\text { Competence matrix of } \\
\text { Master study programmes }\end{array}$ & 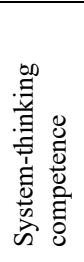 & 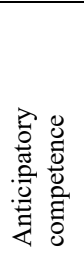 & 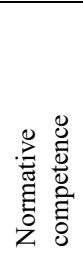 & 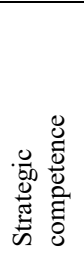 & 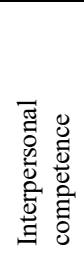 & 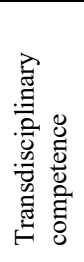 & 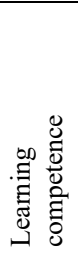 & 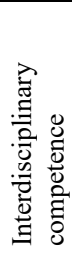 \\
\hline Biobased Materials & 3 & 4 & 3 & 3 & 3 & 4 & 4 & 4 \\
\hline Bio Inspired innovation & 4 & 3 & 3 & 3 & 4 & 4 & 4 & 4 \\
\hline $\begin{array}{l}\text { Biobased Sciences and Biosystems } \\
\text { Engineering (and Biotechnology) }\end{array}$ & 4 & 3 & 3 & 4 & 3 & 4 & 4 & 4 \\
\hline $\begin{array}{l}\text { Management of Bioeconomy, Innovation and } \\
\text { Governance }\end{array}$ & 4 & 3 & 3 & 4 & 3 & 4 & 3 & 4 \\
\hline Industrial Biotechnology & 3 & 4 & 3 & 4 & 4 & 3 & 4 & 4 \\
\hline Bioeconomy & 4 & 4 & 3 & 4 & 3 & 4 & 4 & 4 \\
\hline Forest Sciences & 3 & 4 & 4 & 3 & 3 & 3 & 4 & 3 \\
\hline European Forestry & 4 & 3 & 3 & 3 & 4 & 4 & 4 & 4 \\
\hline $\begin{array}{l}\text { European Master in Bioeconomy in the } \\
\text { Circular economy }\end{array}$ & 4 & 3 & 4 & 3 & 4 & 4 & 4 & 4 \\
\hline $\begin{array}{l}\text { European Master in Biological and Chemical } \\
\text { Engineering for a Sustainable Bioeconomy }\end{array}$ & 4 & 3 & 3 & 3 & 3 & 4 & 4 & 4 \\
\hline Legend: & \multirow{2}{*}{\multicolumn{8}{|c|}{$\begin{array}{l}\text { moderate integration } \\
\text { good integration }\end{array}$}} \\
\hline 4 & & & & & & & & \\
\hline
\end{tabular}




\section{Conclusions}

For the achievement of Green deal, new thinking, learning, teaching and acting strategies should be used. The transition towards bioeconomy is a challenging process and requires cooperation of different stakeholders. Universities, one of the main stakeholders in creation of innovation and sustainable invention, play an important role in implementation of bioeconomy goal through preparation of bioeconomy professionals. Bioeconomy programmes graduates will be the protagonists of a transformation to sustainable bioeconomy and will need to apply acquitted competences and knowledge in creation of new technologies and green innovations in general. This article has reviewed the indicators of sustainable innovation and bioeconomy and sustainable development competences for the education for bioeconomy. Defined competences include transdisciplinary competence, learning competence, interdisciplinary competence and systemthinking competence, anticipatory competence, normative competence, strategic competence and interpersonal competence. All of these competences have showed to be the most important for the implementation of bioeconomy goals and transformation to knowledge-based sustainable bioeconomy.

The analysis of 10 Master study programmes on bioeconomy revealed that the overall bioeconomy and sustainable development competences are strongly integrated into study programmes.

Authors state that more research is needed on the link between the integration of the competences and green innovations. Definition of competences is only one of the steps in the integration of sustainable bioeconomy and is only a part of a broader process, combined with knowledge, skills, intellectual capital and inventions for sustainable bioeconomy.

\section{ACKNOWLEDGEMENT}

This work has been supported within the project "Assessment of the Students' Competences in Higher Education and their Development Dynamics during Study Period" ESF 8.3.6.2. "Development of Education Quality Monitoring System" No. 8.3.6.2/17/I/001 (23-12.3e/19/103).

\section{REFERENCES}

[1] European Commission. 2018. Communication from the commission to the European parliament, the council, the European economic and social committee and the committee of the regions. A sustainable Bioeconomy for Europe: Strengthening the connection between economy, society and the environment. [Online]. [Accessed 15.03.2020]. Available: https://eur-lex.europa.eu/legal-content/EN/TXT/?uri=CELEX\%3A52018DC0673

[2] Levidow L., Birch K., Papaioannou T. Divergent Paradigms of European Agro-Food Innovation: The KnowledgeBased Bio-Economy (KBBE) as an R\&D Agenda. Science, Technology \& Human Values 2012:38(1):1-32. https://doi.org/10.1177/0162243912438143

[3] Anghel I., Siminica M., Cristea M., Noja G. G., Sichigea M. Bioeconomy credentials and intellectual capital: a comparative modelling approach for the E.U.-13 and E.U.-15 2019. Economic Research 2019:32(1):2699-2722. https://doi.org/10.1080/1331677X.2019.1653212

[4] Bildirici M., Ozaksoy F. An analysis of biomass consumption and economic growth in transition countries. Economic Research 2018:31(1):386-405. https://doi.org/10.1080/1331677X.2018.1427610

[5] Braha K., Qineti A., Serences R. Innovation and economic growth: The case of Slovakia. Visegrad Journal on Bioeconomy and Sustainable Development 2015:4(1):7-13. https://doi.org/10.1515/vjbsd-2015-0002

[6] Zilberman D., Gordon B., Hochman G., Wesseler J. Economics of sustainable development and the bioeconomy. Applied Economic Perspectives and Policy 2018:40(1):22-37. https://doi.org/10.1093/aepp/ppx051

[7] Fonseca S. C., Pinheiro R., Barbosa C., Araujo A., Vaz-Velho M., Alves R. Food innovation and entrepreneurship in higher education: A case study. International Journal of Food Studies 2015:4(2):141-147. https://doi.org/10.7455/ijfs/4.2.2015.a3 
[8] Urmetzer S., Pyka A. Varieties of knowledge-based bioeconomies. In Dabbert S., Lewandowski I., Weiss J., Pyka A. Knowledge-driven developments in the bioeconomy. Economic complexity and evolution. Springer 2017:57-82. https://doi.org/10.1007/978-3-319-58374-7

[9] European Commission. 2019. Communication from the commission to the European parliament, the European council, the council, the European economic and social committee and the committee of the regions. The European green deal. [Online]. [Accessed 15.03.2020]. Available: https://ec.europa.eu/info/sites/info/files/european-green-dealcommunication_en.pdf

[10] Golembiewski B. ., Sick N., Bröring S. The emerging research landscape on bioeconomy: what has been done so far and what is essential from a technology and innovation management perspective? Innovative Food Science \& Emerging Technologies 2015:29:308-317. https://doi.org/10.1016/j.ifset.2015.03.006.

[11] Van Lancker J., Wauters E., Van Huylenbroeck G. Managing innovation in the bioeconomy: An open innovation perspective. Biomass and Bioenergy 2016:90:60-69. https://doi.org/10.1016/j.biombioe.2016.03.017

[12] Lozano R. Carpenter A., Satric V. Fostering green chemistry through a collaborative business model: A Chemical Leasing case study from Serbia. Resource Conservation, Recycling 2013:78:136-144. https://doi.org/10.1016/j.resconrec.2013.07.007

[13] Marcon A., Fleith de Medeiros, J., Duarte Ribeiro J. L. Innovation and environmentally sustainable economy: Identifying the best practices developed by multinationals in Brazil. Journal of Cleaner Production 2017:160:83-97. https://doi.org/10.1016/j.jclepro.2017.02.101.

[14] Montalvo C. Sustainable production and consumption systems - cooperation for change: assessing and simulating the willingness of the firm to adopt/develop cleaner technologies. The case of the In-Bond industry in northern Mexico. Journal of Cleaner Production 2003:11(4):411-426. https://doi.org/10.1016/S0959-6526(02)00063-X

[15] Montalvo C. General wisdom concerning the factors affecting the adoption of cleaner technologies: a survey 19902007. Journal of Cleaner Production 2008:16(1):7-13. https://doi.org/10.1016/j.jclepro.2007.10.002

[16] Zailani S., Jeyaraman K., Vengadasan G., Premkumar R. Sustainable supply chain management (SSCM) in Malaysia: a survey. International Journal of Production Economics 2012:140(1):330-340. https://doi.org/10.1016/j.ijpe.2012.02.008

[17] Chen Y.S. The driver of green innovation and green image - green core competence. Journal of Business Ethics 2007: 81(3):531-543. https://doi.org/10.1007/s10551-007-9522-1

[18] Chen Y. S. The positive effect of green intellectual capital on competitive advantages of firms. Journal of Business Ethics 2008:77:271-286. https://doi.org/10.1007/s10551-006-9349-1

[19] Chen Y. S., Chang C. H. The determinants of green product development performance: green dynamic capabilities, green transformational leadership, and green creativity. Journal of Business Ethics 2013:116(1):107-119. https://doi.org/10.1007/s10551-012-1452-x

[20] Caniglia G., Luederitz C., Groß M., Muhr M., John B., Withycombe Keeler L., Wehrden H., Laubichler M., Wiek A., Lang D. Transnational collaboration for sustainability in higher education: Lessons from a systematic review. Journal of Cleaner Production 2017:168:764-779. https://doi.org/10.1016/j.jclepro.2017.07.256

[21] Ardoin N. M., Bowers A. W., Gaillard E. Environmental education outcomes for conservation: A systematic review. Biological Conservation 2020:241:108224. https://doi.org/10.1016/j.biocon.2019.108224

[22] Thurer M., Tomasevic I., Stevenson M., Qu T., Huisingh D. A systematic review of the literature on integrating sustainability into engineering curricula. Journal of Cleaner Production 2018:181:608-617. https://doi.org/10.1016/j.jclepro.2017.12.130

[23] Schutte G. What kind of innovation policy does the bioeconomy need? New Biotechnology 2018:40(A):82-86. https://doi.org/10.1016/j.nbt.2017.04.003

[24] Wydra S. Measuring innovation in the bioeconomy - Conceptual discussion and empirical experiences. Technology in Society 2020:61:101242. https://doi.org/10.1016/j.nbt.2017.04.003

[25] Ribeiro G., Cherobim A. P. Environment and innovation: discrepancy between theory and research practice. $R A I$ Revista de Administracao e Inovacao 2017:14(1):30-40. https://doi.org/10.1016/j.rai.2016.10.002

[26] Drejerska N. Employment in vs. Education for the bioeconomy. Proceedings of the 8th International Scientific Conference Rural Development 2017. November 2017, Kaunas, Lithuania.

[27] Lang D. J., Wiek A., Bergmann M., Stauffacher M., Martens P., Moll P., Swilling M., Thomas C. J. Transdisciplinary research in sustainability science: practice, principles, and challenges. Sustainability Science 2012:7:25-43. https://doi.org/10.1007/s11625-011-0149-x

[28] Segalas J., Ferrer-Balas D., Mulder K. F. What do engineering students learn in sustainability courses? The effect of the pedagogical approach. Journal of Cleaner Production 2010:18(3):275-284. https://doi.org/10.1016/j.jclepro.2009.09.012

[29] Tejedor G., Segalas J., Rosas-Casals M. Transdisciplinarity in higher education for sustainability: How discourses are approached in engineering education. Journal of Cleaner Production 2018:175:29-37. https://doi.org/10.1016/j.jclepro.2017.11.085 
[30] Lambrechts W., Mula I., Ceulemans K., Molderez I. The integration of competences for sustainable development in higher education: an analysis of bachelor programmes in management. Journal of Cleaner Production 2013:48:65-73. https://doi.org/10.1016/j.jclepro.2011.12.034

[31] Wiek A., Withycombe L., Redman C. Key competencies in sustainability: a reference framework for academic programme development. Sustainable Science 2011:6:203-218. https://doi.org/10.1007/s11625-011-0132-6

[32] Lask J., Maier J., Tchouga B., Vargas-Carpintero R. The bioeconomist. In: Lewandowski I. Bioeconomy. Shaping the Transition to a Sustainable, Biobased Economy. Springer, 2018.

[33] Repko A. F., Szostak R., Buchenberger M. P. Identifying relevant disciplines and gathering information about the problem. In: Introduction to interdisciplinary studies, 2nd ed. Sage, Thousand Oaks: CA, 2017.

[34] Barth M., Burandt S. Adding the "e-" to learning for sustainable development: challenges and innovation. Sustainability 2013:5:2609-2622. https://doi.org/10.3390/su5062609

[35] Biobased materials. Master study programme description. Maastricht University [Online]. [Accessed 01.03.2020]. Available: https://www.maastrichtuniversity.nl/education/master/master-biobased-materials

[36] Bio Inspired innovation. Master study programme description. Utrecht University [Online]. [Accessed 01.03.2020]. Available: https://www.uu.nl/masters/en/bio-inspired-innovation/study-programme

[37] Biobased Sciences and Biosystems Engineering (and Biotechnology). Master study programme description. Wageningen University and Research [Online]. [Accessed 01.03.2020]. Available: https://www.wur.nl/en/EducationProgrammes/master/MSc-programmes/MSc-Biobased-Sciences.htm.

[38] Management of Bioeconomy, Innovation and Governance. Master study programme description. University of Edinburgh [Online]. [Accessed 01.03.2020]. Available: https://www.ed.ac.uk/studying/postgraduate/degrees/index.php?r=site/view\&edition=2020\&id=769

[39] Industrial Biotechnology. Master study programme description. University of Strathclyde [Online]. [Accessed 01March 2020]. Available: https://www.strath.ac.uk/courses/postgraduatetaught/industrialbiotechnology/.

[40] Bioeconomy. Master study programme description. The University of Hohenheim [Online]. [Accessed 01.03.2020]. Available: https://www.uni-hohenheim.de/en/bioeconomy-masters.

[41] Forest Sciences. Master study programme description. University of Helsinki [Online]. [Accessed 01.03.2020]. Available: https://www.helsinki.fi/en/admissions/degree-programmes/forest-sciences-masters-programme.

[42] European Forestry. Joint Master study programme description. University of Eastern Finland, AgroParisTech, University of Freiburg, University of Lleida, University of Natural Resources and Life Sciences, Transilvania University of Braşov. [Online]. [Accessed 01.03.2020]. Available: https://ec.europa.eu/ploteus/en/content/europeanforestry-master-science-forestry

[43] European Master in Bioeconomy in the Circular economy. Joint Master study programme description. University of Bologna, University of Milano-Bicocca, University of Naples Federico II, University of Turin [Online]. [Accessed 01.03.2020]. Available: http://masterbiocirce.com/program-overview/

[44] European Master in Biological and Chemical Engineering for a Sustainable Bioeconomy. Erasmus Mundus Joint Master study programme description. Paris Institute of Technology for Life, Food and Environmental Sciences, University of Reims-Champagne-Ardenne, Aalto University, Tallinn University of Technology, University of Liège [Online]. [Accessed 01.03.2020]. Available: http://www.bioceb.eu/

[45] The MSc in Management of Bioeconomy, Innovation and Governance Programme Aims [Online]. [Accessed 01.03.2020].Available: $\mathrm{http}: / / \mathrm{www} . s p s . e d . a c . u k / g r a d s c h o o l / p r o s p e c t i v e /$ taught_masters/h_n/msc_management_bioec onomy_innovation_governance/programme_aims 